\title{
Open vs. Percutaneous Pedicle Screw Insertion for Thoracolumbar Traumatic A3 and A4 AO Fractures - 18-Months Follow-Up
}

\section{Comparação entre as técnicas convencional aberta e percutânea para colocação de parafusos pediculares em fraturas toracolombares AO A3 e A4 - seguimento de 18 meses}

\author{
Flávio Ramalho Romero ${ }^{1,2}$ Rodolfo Brum Vieira ${ }^{1,2}$ \\ ${ }^{1}$ Division of Neurosurgery, Faculdade de Medicina de Botucatu, \\ Universidade do Estado de São Paulo, Botucatu, SP, Brazil \\ 2 Neurosurgery, Hospital das Clínicas \& Hospital Unimed Botucatu, \\ Botucatu, SP, Brazil \\ ${ }^{3}$ Department of Orthopedic and Spine Surgery, Universidade do \\ Estado de São Paulo, Botucatu, SP, Brazil
}

Arq Bras Neurocir 2017;36:207-212

\author{
Bruno da Costa Ancheschi ${ }^{3}$
}

\begin{abstract}
Keywords

- thoraco-lumbar fracture

- percutaneous screw fixation

- screw insertion

- minimally invasive spine surgery

Purpose To compare the efficacy and safety of the percutaneous screw fixation (PSF) and the open pedicle screw fixation (OPSF) on thoracolumbar (TL) fracture.

Methods Sixty-four adult patients with TL vertebral fractures who underwent open or percutaneous posterior short-segment transpedicular screw fixation between January of 2013 and September of 2015 were retrospectively reviewed. All patients underwent clinical, radiological and quality of life follow-up for at least 18 months.

Results There was no significant difference in age, gender, time between injury and surgery, and preoperative percentage of anterior column height, preoperative sagittal regional Cobb angle, or kyphotic angle of fractured vertebra between these two groups $(p>0.05)$. There was significantly less intraoperative blood loss in the PSF $(87.6 \pm 24.6 \mathrm{~mL})$ than in the OPSF group $(271.4 \pm 142.6 \mathrm{~mL})(p<0.05)$. The mean surgery time was 62 minutes (range 42-130 minutes) for open and 58 minutes (range 35 to 128 minutes) for percutaneous screw fixation. The surgery time was shorter in the PSF group, but with no statistical significance $(p>0.05)$. The mean Oswestry disability index (ODI) scores after 18-months were $23.12 \pm 8.2$ for the PSF and $24.12 \pm 9.2$ for the OPSF group, without any statistical significance $(p>0.05)$.

Conclusion Both open and percutaneous screw fixations are safe and effective. The percutaneous techniques significantly reduced the intraoperative blood loss compared with the open techniques.
\end{abstract}

\begin{abstract}
Address for correspondence Flávio Ramalho Romero, MD, MSc, PhD, Departamento de Neurologia, Psiquiatria e Psicologia, Distrito de Rubião Júnior s/n - Botucatu - SP, 18.618-970, Brazil (e-mail: frromero@ig.com.br; romeroncr@gmail.com).
\end{abstract}

received

August 5, 2017

accepted

September 14, 2017

published online

October 27, 2017
DOI https://doi.org/

10.1055/s-0037-1607439. ISSN 0103-5355.
Copyright $(2017$ by Thieme Revinter

Publicações Ltda, Rio de Janeiro, Brazil
License terms

c) $(\oplus) \$$ 


\section{Resumo}

\section{Palavras-chave}

- fraturas toracolombares

- fixação percutânea de parafusos

- inserção de parafusos

- cirurgia da coluna minimamente invasiva
Objetivo Comparar a eficácia e segurança das técnicas de fixação convencional e percutânea para fraturas toracolombares.

Métodos Sessenta e quatro pacientes adultos com fraturas da transição toracolombar que foram submetidos a fixação pedicular curta por técnicas aberta convencional e percutânea entre janeiro de 2013 e setembro de 2015 foram retrospectivamente avaliados. Todos foram submetidos a avaliação clínica, radiológica e de qualidade de vida com no mínimo 18 meses do seguimento.

Resultados Não houve diferença significativa na idade, sexo, tempo entre o trauma e o tratamento, porcentagem da redução da altura do corpo vertebral pré-operatório, angulo de Cob sagital na região da fratura, ou ângulo de de cifose da vértebra fraturada entre os dois grupos $(p>0,05)$. Houve uma menor perda sanguínea no grupo percutâneo $(87,6 \pm 24,6 \mathrm{~mL})$ em comparação com a técnica convencional $(271,4 \pm$ $142,6 \mathrm{~mL})(\mathrm{p}<0,05)$. O tempo médio da cirurgia foi 62 minutos ( $42-130$ minutos) para a técnica convencional e 58 minutos (35 - 128 minutos) para a percutânea. Apesar de mais curto na técnica percutânea, não houve diferença estatisticamente significante no tempo cirúrgico entre os dois grupos ( $p>0,05)$. Em relação ao índice de incapacidade de Oswestry após 18 meses do tratamento cirúrgico, também não houve diferença significante do ponto de vista estatístico entre os dois grupos, sendo 23,12 $\pm 8,2$ para a técnica percutânea e 24,12 $\pm 9,2$ para o grupo da técnica convencional ( $p>0,05$ ). Conclusão Ambas as técnicas mostraram-se eficazes e seguras para o tratamento de fraturas da transição toracolombar. A técnica percutânea apresentou uma taxa de perda sanguínea significativamente menor em comparação à técnica aberta convencional.

\section{Introduction}

The incidence of spinal cord injury (SCI) has been estimated to be between 30 and 40 cases per million, per year, or $\sim$ 10,000 new cases annually. ${ }^{1-5}$ The highest incidence occurs in the 16 - to 30 -year-old range, with $54 \%$ of all injuries. The most frequent cause of SCI has been motor vehicle crash, followed by violence and falls. ${ }^{1,3,6,7}$ Thoracolumbar (TL) fracture accounts for $50-74 \%$ of spinal injuries, with more than $50 \%$ between $\mathrm{T} 11$ and $\mathrm{L}^{7}{ }^{7-11}$ Fifty percent of TL fractures are unstable and can result in significant anatomic injury and deformity. Also, neurological deficit is present in $20-40 \%$ of TL fractures with most paraplegics sustaining trauma in the T11 to L2 spinal segment., ${ }^{1,3-5,7-12}$

Although for some patients with TL fractures without neurologic deficit non-operative treatments obtain good clinical outcomes, many cases have to be submitted to surgical intervention. ${ }^{13-15}$ The surgical treatment of thoracic and lumbar spine fractures depends on various factors because the pathological features of the vertebral lesion, the neurological deficit and the general condition of health affect the treatment and the final result. ${ }^{13-16}$ Many surgical options have been used and, more recently, short-segment pedicle screw fixation (SSPSF) without fusion is widely adopted as an effective treatment with good functional outcomes. ${ }^{17-20}$

There are few studies in the literature comparing these two techniques. Our purpose was to evaluate the long-term follow-up in patients with TL fractures treated with SSPSF and compare open with percutaneous technique.

\section{Methods}

\section{Casuistic}

Patients with TL vertebral fractures who underwent open or percutaneous posterior short-segment transpedicular screw fixation between January of 2013 and September of 2015 at the neurosurgical division of a hospital in Botucatu, SP, Brazil, were retrospectively reviewed. The inclusion criteria were: 1 ) acute A3 or A4 (AO Spine Thoracolumbar Spine Injury Classification System ${ }^{13,14}$ ) TL fracture (T12-L2) at a single level; 2) interval from injury to surgery within 72 hours; and 3 ) follow-up period of more than 18 months. We excluded patients with pathologic fractures, spinal cord or cauda equina injury, or those who had previously received spine surgery due to trauma. The local ethics committee approved the study.

All patients underwent posteroanterior and lateral X-ray examination, computed tomography (CT) scan (including CT in combination with a 3-dimensional reconstruction in some cases), and magnetic resonance imaging (MRI) examination to determine the types of fractures.

\section{Surgical Procedure}

All surgical procedures were performed under general anesthesia. The patients were placed in prone position with the abdomen hanging free through a bolster set under the chest and the iliac crest. The level of the fractured vertebra and the pedicles above and below the injury level were marked by $\mathrm{C}$-arm X-ray examination. In the open pedicle screw fixation (OPSF) technique, the spine was exposed through a routine posterior midline approach. After insertion, the pedicle 


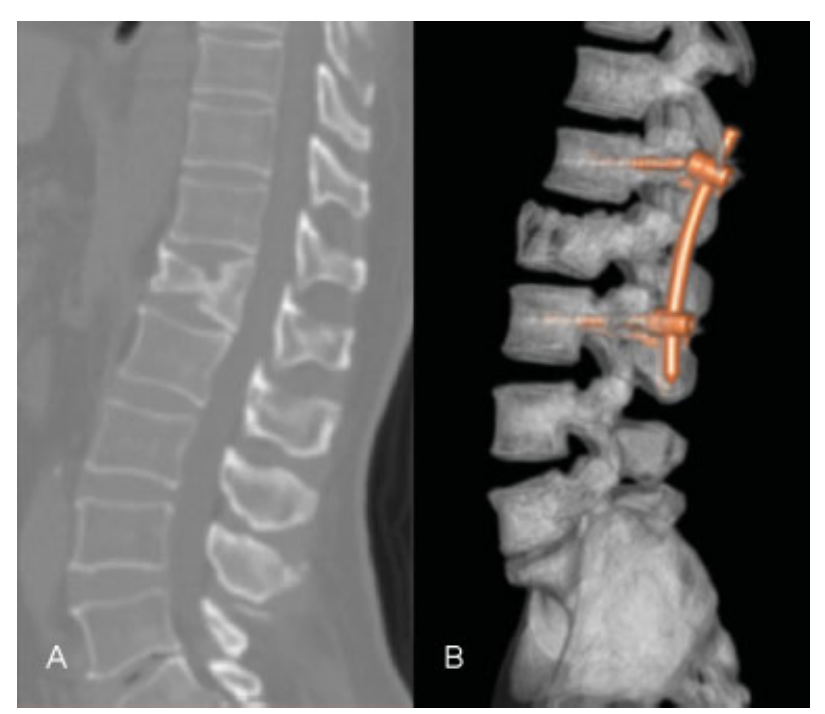

Fig. 1 Case example of the open pedicle screw fixation (OPSF) technique. A. preoperative CT scan sagittal image. B. postoperative CT scan sagittal image.

screws were positioned by C-arm X-ray examination, and were then fixed with rods. Finally, one drainage tube was placed in the suction ( $\mathbf{- F i g . 1} \mathbf{1}$ ).

In the percutaneous screw fixation (PSF) technique, the $2.0 \mathrm{~cm}$ skin incisions were performed above the pedicles markers. Under the C-arm guidance, the needles were inserted through the pedicles into the vertebral bodies, and guide wires were inserted into the vertebral bodies through these needles. Dilation tubes were gradually placed through the guide wire, and the last one was withheld. Pedicles advancing to the junctions between the pedicles and the vertebral body were tapped and then the screw insertions were performed. All the screws had additional towers to guide rod insertion. Then, the rods were inserted through these towers and blocked at the screw heads. Finally, all additional devices were removed and the skin incisions were closed (-Fig. 2).

For all the patients, a first-day postoperative X-ray examination (posteroanterior and lateral) and a CT scan were performed. All patients, except those with fractures in the pelvis or lower limb, were encouraged to walk.

\section{Follow-Up}

All patients underwent clinical, radiological and quality of life follow-up for at least 18 months. Visual analog scale (VAS) for pain, time of hospital stay, and blood loss at procedure were evaluated. X-ray images on posteroanterior and lateral view were performed at 3 months, 12 months, and 18 months after the surgery. Anterior column height, sagittal regional Cobb angle, and fracture kyphotic angle were obtained on lateral $\mathrm{X}$-ray images before and immediately after the surgery, as well as at the final follow-up, using the Osirix (Pixmeo SARL, Bernex, Geneva, Switzerland) medical imaging viewer. The Oswestry Disability Index (ODI) score was used to evaluate the quality of life 18 months after surgery. ${ }^{21}$ The statistical data were analyzed using the SPSS software for Windows V13.0 (SPSS Inc., Chicago, IL, USA). A $p$ value $<0.05$ was considered statistically significant for all the tests.
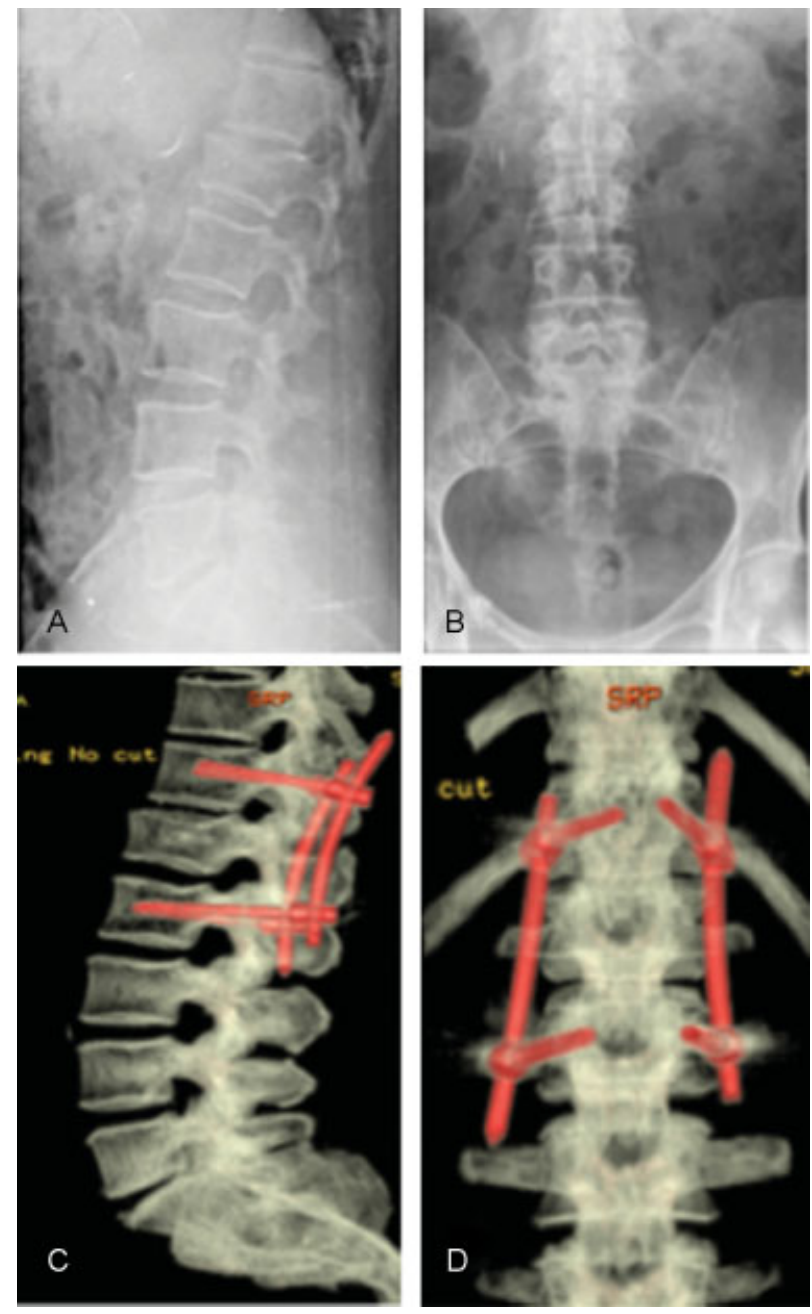

Fig. 2 Case example of the percutaneous screw fixation (PSF) technique. A. Preoperative lateral X-ray image. B. Preoperative anterior X-Ray image. C. Postoperative 3D sagittal CT scan image. D. Postoperative 3D posterior CT scan images.

\section{Results}

Sixty-four adult patients were treated by open or percutaneous posterior short-segment transpedicular screw fixation. The mean age was 36.72 years (range $16-54$ years) and the male to female ratio was $2: 1$. The mean surgery time was 62 minutes (range 42-130 minutes) for OPSF and 58 minutes (range 35 to 128 minutes) for PSF. The demographic data assessed were age, sex, injury mechanisms, injured spine levels, interval between injury and operation, and the preoperative radiological parameters of the fractured vertebra were summarized on - Table 1. There was no significant difference in age, gender, interval between injury and operation, and preoperative percentage of anterior column height, preoperative sagittal regional Cobb angle, or kyphotic angle of the fractured vertebra between these 2 groups ( $p>0.05$, - Table 1$)$.

Surgery time was shorter in the PSF group, but with no statistical significance ( $p>0.05,-$ Table 2$)$. Also, there was no statistically significant difference between these two groups $(p>0.05,-$ Table 2$)$ in the immediate postoperative anterior 
Table 1 Demographic data assessed and preoperative radiological parameters of the fractured vertebra

\begin{tabular}{|c|c|c|c|c|}
\hline & PSF & OPSF & $\mathrm{F} / \mathrm{x}^{2}$ & $P$ \\
\hline Age (years) & 34.32 & 38.64 & 0.837 & 0.439 \\
\hline \multicolumn{5}{|l|}{ Gender } \\
\hline Male & 21 & 22 & & \\
\hline Female & 10 & 11 & & \\
\hline \multicolumn{5}{|l|}{ Injury Mechanism } \\
\hline Traffic accident & 19 & 24 & & \\
\hline Falls & 12 & 09 & & \\
\hline \multicolumn{5}{|l|}{ Fracture level } \\
\hline $\mathrm{T} 12$ & 12 & 08 & & \\
\hline L1 & 11 & 13 & & \\
\hline L2 & 08 & 12 & & \\
\hline Interval between injury and surgery & $3.4 \pm 1.4$ & $3.7 \pm 1.8$ & 0.297 & 0.813 \\
\hline \multicolumn{5}{|l|}{ Radiological preoperative parameters } \\
\hline \% Anterior column height & $66.1 \pm 10.8$ & $67.3 \pm 11.3$ & 1.789 & 0.132 \\
\hline Sagittal Cob angle & $12.1 \pm 6.9$ & $14.3 \pm 6.3$ & 1.873 & 0.147 \\
\hline Kyphotic angle & $16.8 \pm 5.3$ & $17.3 \pm 5.9$ & 1.979 & 0.135 \\
\hline
\end{tabular}

Abbreviations: OPSF, open pedicle screw fixation; $P$, p-value; PSF, percutaneous screw fixation.

Table 2 Outcome data in open pedicle screw fixation (OPSF) and percutaneous screw fixation (PSF)

\begin{tabular}{|l|l|l|l|l|}
\hline & OPSF & PSF & F value & $p$ value \\
\hline Operation time (min) & $62 \pm 18.9$ & $58 \pm 16.4$ & 1.641 & 0.187 \\
\hline Intraoperative. blood loss (mL) & $271.4 \pm 142.6$ & $87.6 \pm 24.6$ & \multicolumn{4}{l|}{} \\
\hline VAS on operative day & $4.2 \pm 2.7$ & $3.8 \pm 2.9$ & 1.748 & 0.05 \\
\hline Hospital stay & $3.2 \pm 2.7$ & $2.3 \pm 3.7$ & 1.879 & 0.165 \\
\hline 18-months follow-up & $4.3 \pm 1.9$ & $3.7 \pm 2.2$ & 1.789 & 0.157 \\
\hline VAS & $24.27 \pm 9.2$ & $23.12 \pm 8.2$ & 1.673 & 0.193 \\
\hline ODI & \multicolumn{5}{|l|}{} \\
\hline Correction parameters & $21 \pm 11.7$ & $17.3 \pm 12.7$ & 8.579 & 0.147 \\
\hline \% anterior column height & $7.5 \pm 6.8$ & $5.7 \pm 5.3$ & 2.387 & 0.057 \\
\hline Sagittal Cobb angle $\left(^{\circ}\right)$ & $9.7 \pm 7.2$ & $6.7 \pm 5.1$ & 5.437 & 0.132 \\
\hline Kyphotic angle $\left(^{\circ}\right)$ &
\end{tabular}

Abbreviations: F values, analisys of variance (ANOVA); ODI, Oswestry disability index; OPSF, open pedicle screw fixation; PSF, percutaneous screw fixation; VAS, visual analog scale,

column height percentage correction, sagittal regional Cobb angle correction, kyphotic fracture angle, hospital stay or pain (VAS) on the first postoperative day. There was significantly less intraoperative blood loss in the PSF $(87.6 \pm 24.6 \mathrm{~mL})$ than in the OPSF group $(271.4 \pm 142.6 \mathrm{~mL})(p<0.05$, - Table 2$)$.

No statistically significant difference was observed in the follow-up period between the two groups $(p>0.05)$. There were no infections in the PSF group and two cases of infection in the OPSF group. Misplacement was found in three cases, with two pedicle screws with a small converging angle in the OPSF group, and one partly out of the pedicle and vertebral body in the PSF group. In addition, there were no cases of screw pull out. Also, no significant difference was observed in the percentage of anterior column height correction, in the sagittal regional Cobb angle loss, or in the kyphotic fracture angle after 18-months follow-up (all $p>0.05$ ). The mean ODI scores after 18 months were $23.12 \pm 8.2$ for the PSF and $24.27 \pm 9.2$ for the OPSF group, and it did not show any statistical significance $(p>0.05)$.

\section{Discussion}

Few studies have compared the efficacy of the PSF versus the OPSF fixation for TL fractures. ${ }^{22-26}$ Our results confirmed that 
both PSF and OPSF are safe and effective for the treatment of TL fractures. ${ }^{22-24}$ Our results indicated obvious correction of the percentage of anterior column height, the sagittal regional Cobb angle, and kyphotic angle of the fractured vertebra in all patients immediately and 18 months after the surgery.

The mean operation time was a little shorter in the PSF group compared with the OPSF group (58 versus 62 minutes), but with no statistical significance. Some other clinical studies reported shorter operation time for percutaneous compared with open techniques. ${ }^{22,23}$ But another study did not show any difference in operation time between these two techniques. ${ }^{24}$ All the procedures of our study were performed by the same senior surgeon, but the percutaneous technique is relatively recent worldwide as well as in our institution. So, one reason for these findings could be explained by the greater experience of our institution with open spine procedures.

There was significantly less intraoperative blood loss in the PSF than in the OPSF group, which is consistent with many other studies. ${ }^{22-26}$ The reasons for this difference were smaller incision and less muscular damage in the PSF group. The OPSF technique required opening all the posterior muscle in the middle line to expose the posterior elements of the vertebras. Our data did not show any mortality and only two cases of superficial wound infection, supporting the conclusion that these two techniques are safe for treatment of TL fractures.

Correction of the percentage of anterior column height of the fractured vertebra did not represent and advantage of the PSF technique in comparison with the OPSF technique, neither did the correction of the sagittal regional Cobb angle and the kyphotic angle of the fractured vertebra. Also, the VAS on surgery day and in the first postoperative day did not represent a statistically significant difference between the PSF and the OPSF group according to the other studies comparing these two techniques. ${ }^{22-24}$ The ODI and VAS in the 18-months follow-up did not exhibit any significant difference. Other studies did not demonstrate any significant differences between these two techniques in the long-term follow-up either. ${ }^{27-30}$

Some limitations are found in our study. First, it was a retrospective study based on reviewing the collected clinical information of the patients. Second, the number of patients included was insufficient for statistical analysis. Third, the follow-up period was relatively short. Thus, future prospective controlled studies with a larger number of patients and longer follow-up period are warranted.

\section{Conclusion}

Both OPSF and PSF are safe and effective for the treatment of TL fractures, with good results at long-term follow-up. Percutaneous screw fixation significantly reduced the intraoperative blood loss compared with OPSF. No significant differences were found between the PSF and the OPSF groups in terms of correction of the percentage of anterior column height, of sagittal regional Cobb angle correction or in the kyphotic angle of fractured vertebra. Also, we found no significant difference in the correction loss angle between the OPSF and PSF fixation groups at the final follow-up.

\section{References}

1 Alpantaki K, Bano A, Pasku D, et al. Thoracolumbar burst fractures: a systematic review of management. Orthopedics 2010;33 (06):422-429

2 Mumford J, Weinstein JN, Spratt KF, Goel VK. Thoracolumbar burst fractures. The clinical efficacy and outcome of nonoperative management. Spine 1993;18(08):955-970

3 Wang ST, Ma HL, Liu CL, Yu WK, Chang MC, Chen TH. Is fusion necessary for surgically treated burst fractures of the thoracolumbar and lumbar spine?: a prospective, randomized study Spine 2006;31(23):2646-2652, discussion 2653

4 Rajasekaran S, Kanna RM, Shetty AP. Management of thoracolumbar spine trauma: An overview. Indian J Orthop 2015;49(01):72-82

5 Stadhouder A, Buskens E, de Klerk LW, et al. Traumatic thoracic and lumbar spinal fractures: operative or nonoperative treatment: comparison of two treatment strategies by means of surgeon equipoise. Spine 2008;33(09):1006-1017

6 Anderson MW. Imaging of Thoracic and Lumbar Spine Fractures. Semin Spine Surg 2010;22:8-19

7 Radcliff K, Su BW, Kepler CK, et al. Correlation of posterior ligamentous complex injury and neurological injury to loss of vertebral body height, kyphosis, and canal compromise. Spine 2012;37(13):1142-1150

8 Keynan O, Fisher CG, Vaccaro A, et al. Radiographic measurement parameters in thoracolumbar fractures: a systematic review and consensus statement of the spine trauma study group. Spine 2006;31(05):E156-E165

9 Reinhold M, Audigé L, Schnake KJ, Bellabarba C, Dai LY, Oner FC. AO spine injury classification system: a revision proposal for the thoracic and lumbar spine. Eur Spine J 2013;22(10):2184-2201

10 Pizones J, Izquierdo E, Alvarez P, et al. Impact of magnetic resonance imaging on decision making for thoracolumbar traumatic fracture diagnosis and treatment. Eur Spine J 2011;20 (Suppl 3):390-396

11 Denis F. The three column spine and its significance in the classification of acute thoracolumbar spinal injuries. Spine 1983;8(08):817-831

12 Magerl F, Aebi M, Gertzbein SD, Harms J, Nazarian S. A comprehensive classification of thoracic and lumbar injuries. Eur Spine J 1994;3(04):184-201

13 Vaccaro AR, Lehman RA Jr, Hurlbert RJ, et al. A new classification of thoracolumbar injuries: the importance of injury morphology, the integrity of the posterior ligamentous complex, and neurologic status. Spine 2005;30(20):2325-2333

14 Vaccaro AR, Oner C, Kepler CK, et al; AOSpine Spinal Cord Injury \& Trauma Knowledge Forum. AOSpine thoracolumbar spine injury classification system: fracture description, neurological status, and key modifiers. Spine 2013;38(23):2028-2037

15 Schroeder GD, Vaccaro AR, Kepler CK, et al. Establishing the injury severity of thoracolumbar trauma: confirmation of the hierarchical structure of the AOSpine Thoracolumbar Spine Injury Classification System. Spine 2015;40(08):E498-E503

16 Vaccaro AR, Schroeder GD, Kepler CK, et al. The surgical algorithm for the AOSpine thoracolumbar spine injury classification system. Eur Spine J 2016;25(04):1087-1094

17 Schroeder GD, Kepler CK, Koerner JD, et al. A worldwide analysis of the reliability and perceived importance of an injury to the posterior ligamentous complex in AO type A fractures. Global Spine J 2015;5(05):378-382

18 Weber BR, Grob D, Dvorák J, Müntener M. Posterior surgical approach to the lumbar spine and its effect on the multifidus muscle. Spine 1997;22(15):1765-1772

19 Foley KT, Gupta SK, Justis JR, Sherman MC. Percutaneous pedicle screw fixation of the lumbar spine. Neurosurg Focus 2001;10(04): E10

20 Anderson DG, Samartzis D, Shen FH, Tannoury C. Percutaneous instrumentation of the thoracic and lumbar spine. Orthop Clin North Am 2007;38(03):401-408, abstract vii 
21 Fairbank JCT, Pynsent PB. The Oswestry Disability Index. Spine 2000;25(22):2940-2952, discussion 2952

22 Lehmann W, Ushmaev A, Ruecker A, et al. Comparison of open versus percutaneous pedicle screw insertion in a sheep model. Eur Spine J 2008;17(06):857-863

23 Charles YP, Zairi F, Vincent C, et al. Minimally-invasive posterior surgery for thoracolumbar fractures: new trends to decrease muscle damage. Eur J Orthop Surg Traumatol 2012; 22:1-7

24 Wang H, Zhou Y, Li C, Liu J, Xiang L. Comparison of Open Versus Percutaneous Pedicle Screw Fixation Using the Sextant System in the Treatment of Traumatic Thoracolumbar Fractures. Clin Spine Surg 2017;30(03):E239-E246

25 Schmidt OI, Strasser S, Kaufmann V, Strasser E, Gahr RH. Role of early minimal-invasive spine fixation in acute thoracic and lumbar spine trauma. Indian J Orthop 2007;41(04):374-380
26 Merom L, Raz N, Hamud C, Weisz I, Hanani A. Minimally invasive burst fracture fixation in the thoracolumbar region. Orthopedics 2009;32(04):273-278

27 Palmisani M, Gasbarrini A, Brodano GB, et al. Minimally invasive percutaneous fixation in the treatment of thoracic and lumbar spine fractures. Eur Spine J 2009;18(Suppl 1):71-74

28 Gelb D, Ludwig S, Karp JE, et al. Successful treatment of thoracolumbar fractures with short-segment pedicle instrumentation. J Spinal Disord Tech 2010;23(05):293-301

29 Kim HY, Kim HS, Kim SW, Ju CI, Lee SM, Park HJ. Short segment screw fixation without fusion for unstable thoracolumbar and lumbar burst fracture: A prospective study on selective consecutive patients. J Korean Neurosurg Soc 2012;51(04):203-207

30 Khare S, Sharma V. Surgical outcome of posterior short segment trans-pedicle screw fixation for thoracolumbar fractures. J Orthop 2013;10(04):162-167 